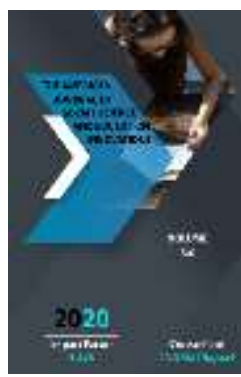

\title{
The Problem Of Mutual Synthesis Of Folklore And Written Literature In The Science Of Karakalpak Literature
}

\author{
Ayimbetova Zamira Maksetbay Kyzy \\ PhD Student, Karakalpak State University Named After Berdakh, Uzbekistan
}

Journal Website: http://usajournalshub.c om/index,php/tajssei

Copyright: Original content from this work may be used under the terms of the creative commons attributes 4.0 licence.

\section{ABSTRACT}

The study of folklore in the works of Karakalpak poets and writers is especially relevant in the modern stages of cultural development, due to the growing interest of society in the study of their national and historical roots. The study of the interrelationship of written literature and folklore is of particular importance in the preservation of the common cultural heritage of mankind and each nation. It is also a powerful weapon in identifying peoples, nations, communities, and age groups and bringing them closer together. Traditional folk culture is not only a dialogue between different nations, but also a dialogue between different peoples. Without it, under the influence of popular culture, young people become addicted to stereotypes that are alien to nationalism, a feeling that often puts nationalism second to none. The spirit of the society, which has lost touch with the roots of national culture, weakens, loses its direction in the definition of moral and artistic dignity.

\section{KEYWORDS}

The preservation of the common cultural, formation of professional

\section{INTRODUCTION}

The study of the problems of the formation of professional literary vocabulary of Karakalpak and other Turkic peoples, without hesitation, shows the great importance of folklore heritage in the evolution of literary programs. One of the important directions of Karakalpak literary criticism is the study of the role of folklore in the formation of the aesthetic attitude of writers and poets to the world, its influence on the artistic system (language, plot, series of images, genre). Folklore is characterized as the basis of the creative 
poetics of the art of speech, as an inexhaustible source of national identity, national ideas.

The subject we are talking about is important for both folklore and literature at the same time. According to the scientific opinion, the study of the interaction of literature and folklore (folklore and literature), the emergence of forms and stages of adaptation to the literary programs of the oral profession determines its relevance in the systematictypological plan for.

\section{METHODOLOGY}

Methods of historical-comparative, comparative-typological, artistic-aesthetic and structural analysis were used in this research.

\section{DISCUSSION}

Folklore and literature have distinctive features and at the same time are interconnected autonomous artistic systems, which form the vocabulary of the people.

The Turkic peoples witnessed the emergence of the art of expression and the process of its formation, as well as the influence of folklore programs on the new written literature. "The enrichment of literature and folklore is one of the most fruitful laws of their general development, the preservation and strengthening of the basic principles developed by peoples over the centuries and infused with the humanistic ideas of modern times. The study of such interactions is, of course, of great importance for both folklore and literature ", - said G.Gamzatov [2, 25-p.]. The interdependence of such aesthetic systems is characterized as a unique synthesis of two types of artistic consciousness for different historical periods. The initial stage of the literature is characterized by a direct adaptation of the plots of folklore, as well as the usual narrative and poetic forms. This ensured the simplicity and popularity of the samples. The evolutionary process of artistic thought is influenced by democratic ideas. The folklore context of the formation of the aesthetic structure as a form of folklore is present in modern literature.

"The conscious participation of writers in folk ethics has become known as folklore." [3, 15p.] - wrote literary scholar Dalgat. At the same time, "folklorism" is a manifestation of the fact that the national literature of the twentieth century, especially the literature of backward nations with very little poetic experience, is forgotten at the level of highly developed, mature national literature"[3, 15-p.] indicated. At the same time, this process is directly related to the writers' separate, unique style of work [3, 12-14 pp.].

A.Lazarev once wrote “Проблема изучения фольклоризма русской литературы. 18701890". In his book [1, 18-p.] he tried to divide the use of folklore materials by poets and writers into typological groups: 1) the use of folklore elements in works of art through "unconscious" contact with folklore; 2) the use of elements of folklore and the modernization of its materials through "conscious" communication with folklore.

Of course, such ideas are recognized and confirmed suddenly and uniformly in the science of general literature. That is why, as the leading literary and folklorist scholar K.Maksetov said: "There have been views on folklore and written literature in two directions. The first was to address the connection between literature and folklore in a positive way. They consider folklore as an indivisible branch of literature, and the 
synthesis of folklore and written literature is used as an inertia that strengthens the tendency of the people - instead of matter. They did not understand that the only link between folklore and literature was the use of folklore samples in the form of citations in literary writings. It is a misunderstanding of the connection between folklore and written literature. We have a broad understanding of the relationship between them. Because, just as the people convey folklore to the poet, the poet must rework it to the people with his artistic words. It is obvious that the interrelationship between folklore and literature is a natural transformation of any naturalism and citation.

Others did not pay enough attention to the connection between folklore and written literature. It is important to note that they do not know how to use folklore in a creative way, and that they have a strong nigilictic view of folklore. Of course, whether they use written or poetic folklore, it is up to them. There is no compulsive recipe for using folklore." [4, 8-p.].

And the views of Professor K.Maksetov are valuable: folklore and written literature have always been closely linked with each other. Examples of folklore became once written literary memoirs, while folklore variants of written literary memoirs appeared." [4, 8-p.].

In addition, in the field of Russian literature for many years there were methodological debates on this issue between two scholars P.S.Vykhodtsev and L.I.Emelyanov. Thus, L.I.Emelyanov believed that folklore is not an ideal example of a nation for a writer, "the question of the influence of folklore on literature can only be a theoretical question" [5, 194-p.]. According to him, folklore is a tradition, which should be understood not as a "separate witness of individual qualities", but as a tradition [5, 197-p.]. In other words, L.I.Emelyanov accused P.S.Vykhodtsev of defining both folklore and nationalism. In response to this, in the opinion of P.S.Vykhodtsev, these unjustified and unfounded accusations, he found flaws in the hypothesis put forward by L.I.Emelyanov: "Among the" factors of culture "is the" fetishization "of folklore" the frightened researcher tries to prove that folklore is "only a source of aesthetic education". In this case, Vykhodtsev concludes that the issue of folklore is one of the other issues and the content is reduced to zero "[6, 4-p.].

Despite these critics differing views on the extent to which folklore has influenced literature, there is no doubt about the very process of interaction between folklore and literature

But the interplay of literature and folklore is not a mere figment of the imagination, unfortunately, researchers of this subject are often limited to the use of folklore motifs, images, and methods. In our opinion, the meaning of I.A.Ossovetsky's term "folklorism of the artist" is remarkable: "in the sense of the word folklorism of the artist it is based on either the folklore plot, or the system of images, or its poetics, or lexicon, or poetic phraseology. in works, and the application of creativity in structural-artistic elements. At the same time, the defined concept includes figurative-poetic, and linguistic categories..." [7, 129-p.].

At the same time, it should not be forgotten that after the transition to literature, this or that folklore image loses its original content - it now becomes an element of a new artistic system. Therefore, "its new meaning and 
function should restore the composition of folklore, the content of folklore images in its individual functional area" - believes S.Jukas [8, 8-p.]. In other words, folklore materials should be used as a basis for the development of literature, especially for a number of national literatures.

Experience has shown that written literature has made great strides in the artistic expression of the real world, in the understanding of the inner world of the individual. However, it continues to follow folklore traditions that embody national aesthetics and depict stylistic diversity. Oral poetic insights are identified as a catalytic factor in the evolutionary growth of literature. The complex aesthetic system of folk poetic values concentrated in folklore plays the role of a specific "genetic code" of the national art of speech and occurs at all stages of its development.

There are plenty of works devoted to determine folklore and literature, their mutual relations, forms and levels of owning folklore traditions to literature as one metasystem and analyze characteristics of different kinds of folklores in folkloristics and science of literature. To know specific features of appearance and shape of new literature, to comprehend the relativity character of new period literature with literal and esthetic system in the past is considered research object of most works of scientists who study literature. Notably, U.Dalgat [3], G.Gamzatov [2], I.A.Baronina [9], from Kazakh literature M.Khasenov [10], from Karakalpak specialists of literature M.Nurmukhammedov [11], K.Mambetov [12], K.Maksetov [4], S.Bakhadirova [13] and others carried out remarkable research works.
It is quite interesting to learn mutual relevance between literal systems, maintenance of folklore customs in national literature, esthetic importance of the literal structure of different genres stated in modern levels.

The monograph of "Folklore and written literature" ("Folklor ha'm jazba a'debiyat") [12] by K.Mambetov is devoted to learn the process of mutual relativity between folklore and Karakalpak literature. In it, the issue of influence of folklore on the formation and appearance of genres in Karakalpak literature ("the most important and the most extensive thread in national literature"), the importance of folkloric traditions on the work of Karakalpak writers in moral-literal, literalphilosophic context is depicted in all levels of development. As a result of this research, "high moral principles created by nation for ages and their expression with literal consciousness and moral activity are considered the main basis in Karakalpak literature, they usually determine the main fields of literal research and national prose" [12].

Folklorist S.Bakhadirova indicates two positions of forming mutual relations

of esthetic systems stated above. The first one is traditional (includes a great deal of young written literature), it begins by owning simple and clear plots of folklore, improves in developing way which ends with creation of huge epic works. Their outer declarative signs appear in such mutual relation. The second one is concealed way (profound philosophical moral humanistic sources of national folklore works become apparent on deeply turning into written works and folklore), it is defined in literal work depending on levels of writer's skills and talent [13]. 
In the work called "Tales by A.S.Pushkin and folklore of Central Asian nations" (“Сказки А.С.Пушкина и фольклор народов Средней Азии") by M.Nurmukhammedov, influence of folklore of Central Asian nations on work of great Russian poet Pushkin, evolution of folktales traditions in it is analyzed with transformation outlook of them in poet's works, influence of folklore on formation of new genres in written literature is remarkably stated [14].

Modern researches prove that mutual effect of literature-folklore is not defined with some kind of type, view, genre or thematic limits. Literal attitude of both systems is marked with typical features of esthetic outlook of the writer and his experience on literal skills [15, 26p.]. To attitude responsibly towards moralcultural sources of literature, especially to the folklore which founded all genre forms of literature exceed interest on history of your nation, prompts to expand realizing your national typicality [16, 7-p.]. Researchers, firstly, give attention more on language, phrasal, morphological and syntactic features of genre forms of heroic epos of different nations in folklore [17].

We can completely imagine carrying out such kind of interesting literal practical process, especially through mutual opposing dialectical process between Karakalpak poetry (lyrics) in $\mathrm{XIX}$ and literal traditions of folklore. It is known that at those times almost all works of Karakalpak poets were preserved to XX century in completely folklore form. Thus, their written traditions, written poetic form and content have been entirely reset by scientists, a large part of society - the nation. Another amusing event, for example, it is evident truth to the whole nation that there is a folklore version of work "Bozataw" by Azhiniyaz, a well-known classic of written literature traditions.

Furthermore, it is methodologically important to us that professor K.Maksetov as a folklorist scientist brought out interesting and effective thoughts based on written and folklore traditions in early times and these days' facts of literal written heritage on these methods. Also, it is considered arising a serious literal scientific and folkloristic actual problem that K.Maksetov's putting forward the issue of connection (synthesis) between the poem called "The truth about carpet maker woman" ("Gilemshi hayal haqqinda haqiyqatliq") and folkloristic poetry even in limited content. Unfortunately, although these thoughts were raised in 70s of last century by our scientists, special researches about this have not been carried out or theoretical works have not been printed yet. Therefore, it looked peculiar interesting to us to carry out deep and systematic scientific research works on this problem.

Great poet Azhiniyaz whom we stated above, is a talented member of written literature, it seems as if he was not relevant to oral-folkloric heritage. Because, he enriched our national literal poetic world with written literal traditions of whole Eastern literature in that XIX century itself. He often declared his works to the world in written form not in oralfolkloristic form. Some of them have come to our time in folkloristic form among people; some of them preserved in written or manuscript form serve to our national literal world of thoughts nowadays.

Indeed, I.Yusupov is also a master of words as this, who enriched the whole Karakalpak poetry in the beginning of XX and XXI with a variety of contents and forms of world classic 
written literature. Currently, it is quite exceptional to converse about relation of that poet with folklore. It is truth that it would seem as rude nihilistic outlook as K.Maksetov stated above. However, if we carefully observe poet's work, it is evident that he had studied the folklore and took sample from motives, traditions, plots in it. For example, at the rank of great classics of world literature, great Sh.Aytmatov, T.Kayipbergenov [18] who expanded literal realistic prose enriching it in each side, remarked repeatedly that they were also watered by folklore which is stream of national literature. I.Yusupov mentioned in his articles, that he took samples from folklore which is very linked with his work [19].

In our opinion, synthesis of folkloristic and written literal traditions of every poet or writer's work - is considered very deep and composed, natural literal practical issue. Because, no one can say that I did not take any sample from folklore which absorbed our people's blood and soul with mother's milk or I do not use from it as like this or like that. Therefore, synthesis of folkloristic and written literal traditions is attracted at once through patriotism of their conceptual esthetic aims and ideas which were brought out and its pleasantness to society in I.Yusupov's lyrics, too. In some lyrical works, influence of folkloristic traditions even in each poetic form and content, stanza, syllables can be seen obviously. Initially, we can clearly realize characteristic signs of folklore - "Xaliq danalig'i'" [20] as scientists indicated.

\section{CONCLUSION}

Despite the results of scientific-researches stated above or others, it looks distinctly that there is a need to study the issue of mutual effect of these esthetic systems, folkloristicliteral traditions, considering the evolution of literal consciousness (thought) in socialcultural site of XX century.

So, the issue of relations between folklore and written literature is marked as a priorityoriented direction in the fundamental researches system of modern philology of science. Great interest to national sources, moral heritage, research to study the issue of transformation principles of national esthetics, national esthetic resources into written literature draws attention.

\section{REFERENCES}

1. Lazarev A. I. The problem of studying folklore in Russian literature. 1870-1890. Severo-Dvinsk, 1985.

2. Gamzatov G. G. folklore: Mera istorizma. Makhachkala: Nauka DNC, 2010. 370 P.

3. Dalgat U. B. literature and folklore. Moscow: Nauka publ., 1981. 304 P.

4. Maksetov K. folklore and literature. Nokis. "Karakalpakstan", 1975.

5. Emelyanov L. I. methodological issues of folklore studies. - L., 1978.

6. Vykhodtsev P. S. and Dr. History of Russian Soviet literature. Moscow, 1986.

7. Ossovetsky I. A. language of modern Russian poetry and traditional folklore. Moscow, 1977.

8. Zhukas S. on the correspondence of folklore and literature // folklore. Poetics and traditionalism. MOSCOW, 1982. - P. 8.

9. Boronina I. A. classical Japanese novel and folklore tradition. - The role of folklore in the development of the East and East Asia. Moscow "Nauka", 1988.

10. Khasenov M. Sabiyt Mukhanov and folklore. "No," she said. "Gylym", 1980. 
11. Nurmukhamedov M. K. to the question of synthesis and written traditions in Turkic poetry. Tashkent. "Fan", 1980.Pushkin's fairy tales and the folklore of the narodov Middle Asia. Tashkent. "Fan", 1983.

12. Mambetov K. folklore and written literature. Nokis. "Karakalpakstan", 1978.

13. Bahadirova S. folklore and karakalpakskaya Sovetskaya prose. Nukus.

"Karakalpakstan", 1984.

14. Nurmukhamedov M. K. Fairy Tales A. S. Pushkina and narodov's folklore of Middle Asia. Izd-Vo "fan", Tashkent, 1983.

15. Baturina N. V. Literaturno-folklore relations in the Russian language of the XVIII century / / Philological Sciences. Questions of theory and practice. Tambov: certificate, 2015. No. 6 (48): in 2-x ch. ch. 1. pp. 25-28.

16. Uzdenova F. T. genre poem in the literature of the Turkic peoples of the Northern Caucasus: abstract. diss. "what's the matter?" N. Nalchik, 1999. 22 p.

17. Gergokova (Etezova) L. S. language of the Karachay-Balkar heroic epic "Narts". Nalchik Nodded. "I don't know," he said.

18. Kaipbergenov T. the pupil of the eye. Nokis. "Karakalpakstan".

19. Yusupov I. The Word in Taryushka. "The same author. "The current of time". Nokis. "Karakalpakstan", 1972.

20. Aimbetov K. folk wisdom. Nokis. "Karakalpakstan", 1988. 